\title{
Automatic and Efficient Allocation for Examination Seats using Android Application
}

\author{
A.V.Allin Geo, R. Kavitha, R. Velvizhi, S. Sangeetha
}

\begin{abstract}
This paper is resolved to streamline the errand of manual seating game plan of understudies in an examination lobby. The main goal is to develop an android app for automatic examination seating arrangement in addition to reducing the manual work of staff. A PDF containing student exam number with subject code and subject name will be sent by the university and will be received by the admin staff which will be converted into suitable format. Then an algorithm will be used to involuntarily allocate the students to the suitable block according to their strength. Then the staff will be randomly allocated to particular block. Alternating staff allocation will be done according to department. The students and the staff will receive a message regarding the block where they have been assigned. In this paper we can further add features to improve the flexibility.
\end{abstract}

Keywords-Android, MySQL Database, Parsing, PHP

\section{INTRODUCTION}

In several universities examinations are held at regular intervals. Allocating the students to different blocks according to their strength is the main job. But allocating students manually is a hectic job for the staff[1],[3],[5]. So to get rid of this inconvenience this paper is designed to remove the manual work of the staff. We are going to design an android application for this.

In this a database we will maintain a student record with their seat number, staff database and the number of blocks. The subject PDF will be sent by the university to the college and the admin will process this PDF[2 ],[4],[6]. An algorithm will be coded and the arrangement of seats will be done.

These details will be sent to the android application of the staff and student. They are first required to login. The staff and students will get the details regarding which block they are allocated to. Unnecessarily the students and staff need not search different floors or building as they will get the details about it.

Revised Manuscript Received on July 22, 2019.

A.V.Allin Geo, Department of CSE, Bharath Institute of Higher Education and Research, Chennai, Tamilnadu, India.

R. Kavitha Department of CSE, Bharath Institute of Higher Education and Research, Chennai, Tamilnadu, India.

R. Velvizhi, Department of CSE, Bharath Institute of Higher Education and Research, Chennai, Tamilnadu, India.

S. Sangeetha, Department of CSE, Bharath Institute of Higher Education and Research, Chennai, Tamilnadu, India.
Different algorithms are used for the process of sorting, natural selection etc. As the paper is all about decision making so various algorithms regarding decisions will be used to produce as valid output. [37],[39],[41]

This application can be widely used in every college for any kind of exam or even for event management. It reduces our time and makes the procedure very routine.

This paper essentially centers on improving the effectiveness of the seat assignment framework and the tiring errand of physically designating seats to every person[7],[ 9] ,[11]. And also for students to easily find their class rooms during exam so that they can reach the examination hall at time.

\section{LITERATURE SURVEY}

PAPER NAME(1): "automatic seating arrangement tool for examinations in universities/colleges" used the $\mathrm{C} / \mathrm{C}++$ language.

AUTHOR NAME: Aashti Fatima Alam

ANALYSIS: In that they have used the tool which automatically arrange student according to their seat number. They used Dev C++ compiler which is an incorporated advancement condition conveyed under the General Public License for programming in $\mathrm{C}$ and $\mathrm{C}++$. It is packaged with a free compiler called MinGW. [32],[34],[36] PAPER NAME(2): "A study on automatic allocation of membership functions for fuzzy modelling" we studied about the genetic algorithm which is used for automatic function. ) AUTHORNAME:Prof.S.S.Aravinth, G.Pavithra

ANALYSIS: In this paper the main drawback was the notification system. As the seating arrangements are done by the help of tools but then also the students need to go to the notice board to look for their block number. So that drawback was removed in the proposed paper.

PAPER NAME(3): "Exam hall seating arrangement system using PHP"

AUTHOR NAME: Prof S.S.Aravinth,

G.Pavithra

ANALYSIS: This is the online system to provide seating arrangement in which student need to online registration first.it means each student having a registration first individually. [8],[ 10], ,[12]

\section{PROBLEM DEFINITION}

As we know that during the examination the exam coordinator has to look to the number of students attending a particular paper. After that he has to allocate them to the class rooms or blocks according to the number of students

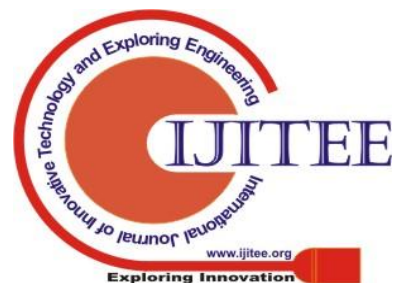


present. So this is a confused task for him as well as the other staffs with him.

In order to make their task easy we will design an application that will mechanize the task of assigning the students to particular block. But with that we need a condition that a specific department should not have the same department staff most likely to reach a goal. [13], [15] ,[ 17]

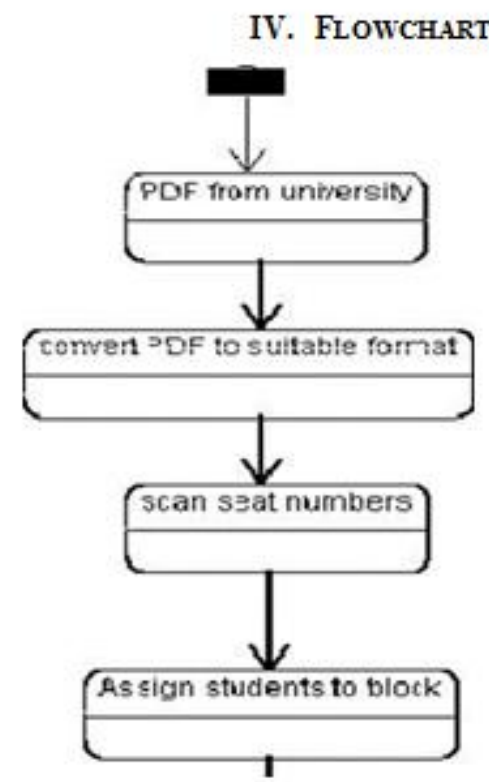

\section{EXISTING SYSTEM}

In the existing system internet is the main medium of communication. Messages can be sent through wireless network in the university or mobile data of students. This existing system has some drawbacks and setbacks which have to be rectified soon to avoid more problematic situations.

\section{PROPOSED SYSTEM}

In the proposed system we will focus on building up an application in android along with back end in PHP. In this there will be several databases containing interrelated information about student, teachers and number of classrooms.

During the time of examination a PDF is sent by the university to college. This PDF is converted into a suitable format. Then an algorithm is used to verify the condition. If the condition is yes then automatic allocation is done. The algorithm is chosen depending on the condition such as natural selection etc. The allocation is done along with details such as number of student, block size, paper code. The staff allocation is also done indiscriminately [31],[33],[35] but the same department staff will not be allocated to same department. When the process is done then the notification will be sent to the staff as to which block they are allocated. The same message is also sent to the students that which block they are allotted to and on which building or floor.

So they need not to search buildings. The above diagram shows in short the flow of the project in an easy way.

a group of information designed to be utilized by numerous human beings is called a database. it's miles a group of interrelated information stored together with managed redundancy to offer one or more packages in a possible style. The information is stored in this sort of style that it does now not depend on the programs of people using the statistics. A common and controlled technique is used in adding new statistics and modifying and retrieving data already gift inside the database. Student details

- Invigilator details

- Room details

- Exam schedule

- Room allocation

and age work reducing applications are much required on account of the expanding request of new patterns. It is a composed framework which permits us to automatically allocate students to their preferred location[14],[ 16], [18]. For people supervising the institutions, the work load is very high and the need for faster work is a need of the hour. There is a typical grievance that administration workplaces have surplus outstanding burden however the speed of viability is extremely low. Programming, for example, these can get our work time. Organisations utilize the product can spare adequate measure of time amid the examination time. A portion of the few preferences of this model are that it is quick, solid and full-bodied. In this day and age, it is the device for occasion the board which is amazingly helpful for different events[19],[21],[23]. This genuinely necessary element of ease of use is available in this model and can be utilized for a wide range of the client whether Agile, Naïve or master.

\section{RESTRICTIONS}

Despite the fact that the model of extraordinary use, there are a few disadvantages such programming believes each space to be of equivalent seating limit[20],[22], [24]. Likewise a lot of information, programming backs off. Now and again, it is totally solid it doesn't take into broken seats and harmed furniture.

\section{ALGORITHMS}

Choice Tree-A choice tree is a choice help tool that makes use of a tree-like graph or version of decisions and their possible effects, inclusive of chance occasion effects, useful resource fees, and utility. it is one manner to symbolize an algorithm. [38],[40],

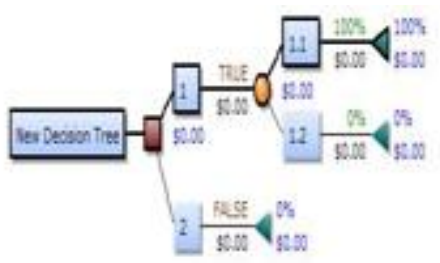

above diagram shows how a decision tree works. It generally helps to decide plans to reach our goal.

Naïve Bayes algorithm-Naive Bayes is a conditional probability model: given a hassle instance to be labeled, represented via vector representing a few $n$ features (impartial variables), it assigns to this example possibilities for each of ok feasible consequences or instructions.

The setback with the above components is that if the variety of features $n$ is large or if a feature can take on a massive number of values, then basing such a version on possibility tables isn't 
possible[25],[27],[29]. We consequently reformulate the[6] model to make it more ideal. the usage of Bayes' theorem, the conditional probability can be decomposed as:

$\mathrm{W}(\mathrm{Ck} \mid \mathrm{x})=\mathrm{A}(\mathrm{Ci}) \mathrm{S}(\mathrm{x} \mid \mathrm{De}) / \mathrm{t}(\mathrm{o})$

In plain English, using Bayesian opportunity terminology, the above equation may be written.

\section{FUTURE SCOPE}

In the future we can use different strategies to find blocks, number of students also for students who do not have internet facilities or android phone then we can send them a message at any time, any place[26],[28],[30]

\section{CONCLUSION}

Here by I conclude that this paper will reduce the work load of the staff. This application further can be adapted by different institutes to reduce their work.

\section{REFRENCES}

[1] Kumarave A., Rangarajan K.,Algorithm for automaton specification for exploring dynamic labyrinths,Indian Journal of Science and Technology,V-6,I-SUPPL5,PP-4554-4559,Y-2013

[2] P. Kavitha, S. Prabakaran "A Novel Hybrid Segmentation Method with Particle Swarm Optimization and Fuzzy C-Mean Based On Partitioning the Image for Detecting Lung Cancer" International Journal of Engineering and Advanced Technology (IJEAT) ISSN: 2249-8958, Volume-8 Issue-5, June 2019

[3] Kumaravel A., Meetei O.N.,An application of non-uniform cellular automata for efficient cryptography,2013 IEEE Conference on Information and Communication Technologies, ICT 2013,V-,I-,PP-1200-1205,Y-2013

[4] Kumarave A., Rangarajan K.,Routing alogrithm over semi-regular tessellations,2013 IEEE Conference on Information and Communication Technologies, ICT 2013,V-,I-,PP-1180-1184,Y-2013

[5] P. Kavitha, S. Prabakaran "Designing a Feature Vector for Statistical Texture Analysis of Brain Tumor" International Journal of Engineering and Advanced Technology (IJEAT) ISSN: 2249-8958, Volume-8 Issue-5, June 2019

[6] Dutta P., Kumaravel A.,A novel approach to trust based identification of leaders in social networks, Indian Journal of Science and Technology,V-9,I-10,PP--,Y-2016

[7] Kumaravel A., Dutta P.,Application of Pca for context selection for collaborative filtering,Middle - East Journal of Scientific Research,V-20,I-1,PP-88-93,Y-2014

[8] Kumaravel A., Rangarajan K.,Constructing an automaton for exploring dynamic labyrinths,2012 International Conference on Radar, Communication and Computing, ICRCC 2012,V-,I-,PP-161-165,Y-2012

[9] P. Kavitha, S. Prabakaran "Adaptive Bilateral Filter for Multi-Resolution in Brain Tumor Recognition" International Journal of Innovative Technology and Exploring Engineering (IJITEE) ISSN: 2278-3075, Volume-8 Issue-8 June, 2019

[10] Kumaravel A.,Comparison of two multi-classification approaches for detecting network attacks, World Applied Sciences Journal,V-27,I-11,PP-1461-1465,Y-2013

[11] Tariq J., Kumaravel A.,Construction of cellular automata over hexagonal and triangular tessellations for path planning of multi-robots,2016 IEEE International Conference on Computational Intelligence and Computing Research, ICCIC 2016,V-,I-,PP--,Y-2017

[12] Sudha M., Kumaravel A.,Analysis and measurement of wave guides using poisson method,Indonesian Journal of Electrical Engineering and Computer Science,V-8,I-2,PP-546-548,Y-2017

[13] Ayyappan G., Nalini C., Kumaravel A.,Various approaches of knowledge transfer in academic social network,International Journal of Engineering and Technology,V-,I-,PP-2791-2794,Y-2017

[14] Kaliyamurthie, K.P., Sivaraman, K., Ramesh, S. Imposing patient data privacy in wireless medical sensor networks through homomorphic cryptosystems 2016, Journal of Chemical and Pharmaceutical Sciences 92.

[15] Kaliyamurthie, K.P., Balasubramanian, P.C. An approach to multi secure to historical malformed documents using integer ripple transfiguration 2016 Journal of Chemical and Pharmaceutical Sciences 92
A.Sangeetha,C.Nalini,"Semantic Ranking based on keywords extractions in the web", International Journal of Engineering \& Technology, 7 (2.6) (2018) 290-292

[17] S.V.GayathiriDevi,C.Nalini,N.Kumar,"An efficient software verification using multi-layered software verification tool "International Journal of Engineering \& Technology, 7(2.21)2018 454-457

[18] C.Nalini,ShwtambariKharabe,"A Comparative Study On Different Techniques Used For Finger - Vein Authentication", International Journal Of Pure And Applied Mathematics, Volume 116 No. 8 2017, 327-333, Issn: 1314-3395

[19] M.S. Vivekanandan and Dr. C. Rajabhushanam, "Enabling Privacy Protection and Content Assurance in Geo-Social Networks", International Journal of Innovative Research in Management, Engineering and Technology, Vol 3, Issue 4, pp. 49-55, April 2018.

[20] Dr. C. Rajabhushanam, V. Karthik, and G. Vivek, "Elasticity in Cloud Computing", International Journal of Innovative Research in Management, Engineering and Technology, Vol 3, Issue 4, pp. 104-111, April 2018.

[21] K. Rangaswamy and Dr. C. Rajabhushanamc, "CCN-Based Congestion Control Mechanism In Dynamic Networks", International Journal of Innovative Research in Management, Engineering and Technology, Vol 3, Issue 4, pp. 117-119, April 2018.

[22] Kavitha, R., Nedunchelian, R., "Domain-specific Search engine optimization using healthcare ontology and a neural network backpropagation approach", 2017, Research Journal of Biotechnology, Special Issue 2:157-166

[23] Kavitha, G., Kavitha, R., "An analysis to improve throughput of high-power hubs in mobile ad hoc network" , 2016, Journal of Chemical and Pharmaceutical Sciences, Vol-9, Issue-2: 361-363

[24] Kavitha, G., Kavitha, R., "Dipping interference to supplement throughput in MANET", 2016, Journal of Chemical and Pharmaceutical Sciences, Vol-9, Issue-2: 357-360

[25] Michael, G., Chandrasekar, A.,'Leader election based malicious detection and response system in MANET using mechanism design approach", Journal of Chemical and Pharmaceutical Sciences(JCPS) Volume 9 Issue 2, April - June 2016

[26] Michael, G., Chandrasekar, A.,"Modeling of detection of camouflaging worm using epidemic dynamic model and power spectral density", Journal of Chemical and Pharmaceutical Sciences(JCPS) Volume 9 Issue 2, April - June 2016

[27] Pothumani, S., Sriram, M., Sridhar, J., Arul Selvan, G., Secure mobile agents communication on intranet,Journal of Chemical and Pharmaceutical Sciences, volume 9, Issue 3, Pg No S32-S35, 2016

[28] Pothumani, S., Sriram, M., Sridhar , Various schemes for database encryption-a survey, Journal of Chemical and Pharmaceutical Sciences, volume 9, Issue 3, Pg NoS103-S106, 2016

[29] Pothumani, S., Sriram, M., Sridhar, A novel economic framework for cloud and grid computing, Journal of Chemical and Pharmaceutical Sciences, volume 9, Issue 3, Pg No S29-S31, 2016

[30] Priya, N., Sridhar, J., Sriram, M. "Ecommerce Transaction Security Challenges and Prevention Methods- New Approach” 2016 ,Journal of Chemical and Pharmaceutical Sciences, JCPS Volume 9 Issue 3.page no:S66-S68

[31] Priya, N.,Sridhar,J.,Sriram, M."Vehicular cloud computing security issues and solutions" Journal of Chemical and Pharmaceutical Sciences(JCPS) Volume 9 Issue 2, April - June 2016

[32] Priya, N., Sridhar, J., Sriram, M. "Mobile large data storage security in cloud computing environment-a new approach" JCPS Volume 9 Issue 2. April - June 2016

[33] Anuradha.C, Khanna.V, "Improving network performance and security in WSN using decentralized hypothesis testing "Journal of Chemical and Pharmaceutical Sciences(JCPS) Volume 9 Issue 2, April - June 2016.

[34] Anuradha.C, Khanna.V, "A novel gsm based control for e-devices" Journal of Chemical and Pharmaceutical Sciences(JCPS) Volume 9 Issue 2, April - June 2016 .

[35] Anuradha.C, Khanna.V, "Secured privacy preserving sharing and data integration in mobile web environments " Journal of Chemical and Pharmaceutical Sciences(JCPS) Volume 9 Issue 2, April - June 2016

[36] Sundarraj, B., Kaliyamurthie, K.P. Social network analysis for decisive the ultimate classification from the ensemble to boost accuracy rates 2016 International Journal of Pharmacy and Technology 8

[37] Sundarraj, B., Kaliyamurthie, K.P. A content-based spam filtering approach victimisation artificial neural networks 2016 International Journal of Pharmacy and Technology $\quad 8 \quad 3$.

[38] Sundarraj, B., Kaliyamurthie, K.P. Remote sensing imaging for satellite image segmentation2016 International Journal of Pharmacy and Technology 83.

[39] Sivaraman, K., Senthil, M. Intuitive driver proxy control using artificial intelligence 2016 International Journal of Pharmacy and Technology 84. 
[40] Sivaraman, K., Kaliyamurthie, K.P.Cloud computing in mobile technology 2016 Journal of Chemical and Pharmaceutical Sciences 92.

[41] Sivaraman, K., Khanna, V. Implementation of an extension for browser to detect vulnerable elements on web pages and avoid click jacking 2016 Journal of Chemical and Pharmaceutical Sciences 92.

\section{AUTHORS PROFILE}

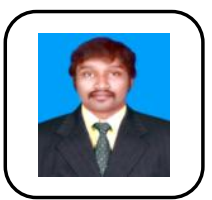

A.V.Allin Geo, Assistant Professor, Department of Computer Science \& Engineering, Bharath Institute of Higher Education and Research, Chennai, India

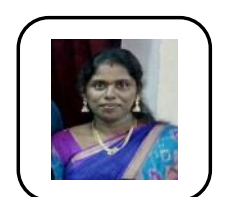

R.Kavitha, Associate Professor, Department of Compute Science \& Engineering, Bharath Institute of Higher Education and Research, Chennai, India

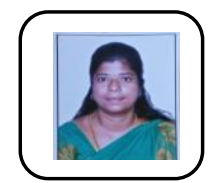

R. Velvizhi, Associate Professor, Department of Computer Science \& Engineering, Bharath Institute of Higher Education and Research, Chennai, India

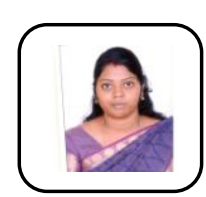

S. Sangeetha, Assistant Professor, Department of Computer Science \& Engineering, Bharath Institute of Higher Education and Research, Chennai, India 